\title{
Hebrew Incunabula in Spanish Libraries: Recent Findings and Updated Census
}

Esperanza Alfonso and Javier del Barco

ILC-CCHS, CSIC (Madrid)

\begin{abstract}
The authors report on the existence of three hitherto unknown copies of Hebrew incunabula printed in Soncino, provide a full description and discussion of a copy of an incunabulum from Leiria, and fragments of an incunabulum from Hijar, which they had previously identified, and offer an updated list of all the Hebrew incunabula extant in Spanish libraries and archives.
\end{abstract}

\section{Keywords}

Incunabula, Iberian Peninsula, Hebrew book, Leiria, Soncino

The following pages are intended to add a footnote to the history of Hebrew incunabula produced in the Iberian Peninsula and Italy by bringing attention to the existence of three hitherto unknown copies of Hebrew incunabula from Soncino and a copy - not included in standard repertoires of incunabula - of an incunabulum from Leiria. This article also provides a full description of various fragments from a previously identified copy of an incunabulum from Híjar, as well as an updated list of all the known Hebrew incunabula extant in Spanish libraries and archives.

The copy from Leiria was printed by Samuel Dortas, at an unknown date sometime between 1492 and 1496. It was bound with an assortment of manuscript texts into a single volume: San Lorenzo de El Escorial, Real Biblioteca (hereinafter RBSLE), MS G-IV-5. The three incunabula from Soncino were printed by Joshua Solomon 
Soncino between 1484 and 1485, and they were bound together in a single volume: RBSLE, 83-VII-23.

\section{The incunabulum from Leiria}

This copy has been bound together with manuscript materials at the RBSLE, which is why the codex that contains is classified in the library's Hebrew manuscripts section (MS G-IV-5) rather than with the other printed copies belonging to the library. ${ }^{1}$

\section{a) The book and its contents}

Sefer Halikhot 'Olam [Methodology of the Talmud], by Jeshua ben Joseph Halevi, with Sefer ha-Yir'ah [Book of Religious Fear], by Jonah Gerondi, and Sod ha-Teshuvah [Secret of Repentance], by Jonah Gerondi [Leiria: Samuel Dortas, between 1492 and 1496].

The book is described in: Adler, 39; Amzalak, p. 28; Anselmo, 7; BHB, 000139373; BiblPort, 5-7; Bod-inc, Heb 50; CIBN, Heb-34; Cowley, p. 319; Freimann, Ink, p. 117; Friedberg, 104 [א]; Friedberg, BES, ה 704, 1; Goff, Heb-63; Goldstein, 102; GW, MII941; Haebler, BI 345; HSTC 278; Iakerson, JTS, 108; ISTC, ij00219500; ${ }^{2}$ Jacobs 66; Madsen, 4319; Meyer, 278; Marx, 64; Meyer and Sáenz Badillos, 142;

Offenberg, BMC, p. 103; Offenberg, Census, 78; Pr., 9838; Schwab, 87; St.CB, 5817, 1; STCSp-Port, p. 136; Thes, B 28; Thomas, p. 136; TishbyIsr, 30; Vindel, IX, 16; Vinograd, 1; Zedner, p. 783.

\footnotetext{
${ }^{1}$ In the description of the copies, we follow with minor modifications the standards set up in A. K. Offenberg, Catalogue of Books Printed in the Fifteenth Century Now in the British (Museum) Library. Part XIII, Hebraica (London 2004).

${ }^{2}$ We have already reported to ISTC the existence of this copy from Leiria.
} 
For a complete, comprehensive description of the edition, see Iakerson, JTS, 108, and Offenberg, BMC, p. 103. For a complete list of libraries holding copies of this incunabulum, see ISTC, ij00219500, and Offenberg, Census, 78.

Very little is known about Jeshua ben Joseph Halevi (fifteenth century) other than what the author himself reports in the introduction to his Sefer Halikhot 'Olam. In it he says that he fled Tlemcen, his native town, after the persecutions of Jews in Algiers in 1467, and later reached Castile and settled in Toledo, where he wrote this popular methodology of the Talmud, commissioned by the nasi' Don Vidal ben Lavi, which was reprinted five times in the $16^{\text {th }}$ century. ${ }^{3}$

More is known about the life, intellectual profile and works of Jonah ben Abraham Gerondi (Girona c. 1200-Toledo 1263). The two works by this author included in the book are on ethics and present a program of pietistic behaviour. With a focus on piety, prayer and repentance, they bear the clear influence of the German pietists, a body of work which the author would have become familiar with during his time at the French yeshivot of Evreux. A. Löwenthal was the first to discover that the Sefer ha-Yir'ah was identical to a booklet entitled Hayye 'Olam. ${ }^{4}$ There is some disagreement about the authorship of this work (Sefer ha-Yir'ah/Hayye 'Olam): while some scholars consider it to be by Jonah Gerondi, others reject this attribution. ${ }^{5}$ As for Sod ha-Teshuvah, the work is also known as Yesod ha-Teshuvah [The Foundation of

\footnotetext{
${ }^{3}$ See Y. Horowitz, 'Jeshua ben Joseph Ha-Levi,' in: M. Berenbaum and F. Skolnik, Encyclopaedia Judaica, 2nd ed. (Detroit 2007), vol. 11, p. 242.

${ }^{4}$ A. Löwenthal, 'Sefer Hayye 'Olam', in: Festschrift zum achtzigsten Geburtstage... Wolf Feilchenfeld (Pleschen-Schrimm 1907), 66-76 (as quoted in: A.T. Shrock, Rabbi Jonah ben Abraham of Gerona: His Life and Ethical Works [London 1948], p. 92).

${ }^{5}$ On the manuscript copies of this work, see Shrock, op. cit. (n. 4), pp. 88-92; on the title of the work and the debate about its authorship, see ibid., pp. 92-5; B. Richler, “Al kitve ha-yad shel Sefer ha-Yir'ah hameyuhas le-Rabbenu Yonah Gerondi', 'Ale Sefer, 8 (1980), pp. 51-9, and the literature mentioned in nn. 1-2; E. Kanarfogel, 'Peering through the Lattices': Mystical, Magical, and Pietistic Dimensions in the Tosafist Period (Detroit 2000), pp. 62-7, with further discussion and literature in nn. 84-5.
} 
Repentance] and as Seder Darke ha-Teshuvah [The Order of Paths of Repentance]. ${ }^{6}$ In some of the manuscripts it is attributed to other authors. ${ }^{7}$

\section{b) Special characteristics of the RBSLE copy}

Collation: $1-11^{8} 12^{4} 13-14^{8} 15^{8-1}$ (without 15.8 , blank). 115 leaves. 12.4 blank.

Contents:

$\begin{array}{lrl}100^{\mathrm{r}}\left[1^{\mathrm{a}}\right] & 1.1^{\mathrm{a}} & \text { Beginning of Halikhot 'Olam } \\ {[192][92]} & 12.4 & \text { Blank } \\ 192^{\mathrm{r}} \text { bis }\left[93^{\mathrm{a}}\right] & 13.1^{\mathrm{a}} & \text { Beginning of Sefer ha-Yir'ah } \\ 210^{\mathrm{r}}\left[111^{\mathrm{a}}\right], 1.13 & 15.3^{\mathrm{a}} & \text { Beginning of Sod ha-Teshuvah } \\ 214^{\mathrm{r}}\left[115^{\mathrm{a}}\right], 1.18 & 15.7^{\mathrm{a}} & \text { End } \\ 215^{\mathrm{v}}\left[115^{\mathrm{b}}\right] & 15.7^{\mathrm{b}} & \text { Blank }\end{array}$

The copy under examination here is in pristine condition, apart from occasional moisture stains and some damage caused by wood-boring insects. Unlike other extant copies, it bears no traces of expurgation, no signs of censorship, and no names of owners whatsoever. In Samuel Dortas's edition there is no foliation. The printed text was later numbered as part of the manuscript miscellany, beginning at f. 100 (ff. $100^{\mathrm{r}}-214^{\mathrm{r}}$ in G-IV-5). ${ }^{8}$ A hand, in all likelihood identical to the one foliating the texts, added two notes on f. $100^{\mathrm{r}}$ in G-IV-5 [= $\left.1^{\mathrm{a}}\right]$ : '78 Impreso' in the left part of the header and 'Hispanus auctor' in the upper left margin.

\section{d) RBSLE, MS G-IV-5}

\footnotetext{
${ }^{6}$ See Shrock, op. cit. (n. 4), pp. 69-78.

${ }^{7}$ See Kanarfogel, op. cit. (n. 5), p. 65, n. 88.

${ }^{8}$ The volume displays three different foliations: ff. $1-279$, foliation in pencil in the left part of the header on the rectos; identical foliation in pencil in the right part of the header in the previous versos, with omissions which include the printed text. Beginning in $\mathrm{f}$. 216 the number on the previous versos has been crossed out; from 239 to 242 the correct verso number has been added: $238^{\mathrm{v}}$ (for 239 crossed out), etc. From f. 243, there is an alternative foliation, beginning in f. 225 bis. Blank folios are left unnumbered.
} 
The codex has been described by N. Allony and E. Kupfer (who list the first and second works in the printed text) $;^{9} \mathrm{~J}$. Llamas (who lists the first work) ${ }^{10} \mathrm{~J}$. del Barco (who lists the first work). ${ }^{11}$ The online catalogue of the Jewish National and University Library (hereinafter JNUL) in Jerusalem lists all three works and further indicates that they were apparently printed in Lisbon/Sepharad, in $1490 .{ }^{12}$ They all indicate the presence of a printed text within the manuscript codex but do not identify the edition. ${ }^{13}$

The fact that the first text in the miscellany is Jonah b. Abraham Gerondi's commentary on the tractate Avot [Fathers] (ff. $1^{\mathrm{r}}-62^{\mathrm{v}}$ ) was probably a decisive factor in the inclusion of the incunabulum within the codex. The miscellany contains two other sets of texts, divided - perhaps accidentally - by the printed text. In ff. $63^{\mathrm{r}}$ to $98^{\mathrm{v}}$, most texts fall into the category of belletristic literature, and many are authored by Jewish scholars from Provence: a miscellany of short texts by various authors (ff. $63^{\mathrm{r}}-64^{\mathrm{r}}$ ); Minhat Yehudah Sone’ ha-Nashim [The Offering of Judah, the Misogynist], by Judah ben Isaac ibn Shabbetai (ff. $65^{\mathrm{r}}-86^{\mathrm{v}}$ ); Poem of the Aleph, by Joseph ben Sheshet ibn Latimi (ff. $87^{\mathrm{r}}-89^{\mathrm{v}}$ ); Baqqashat ha-Memin [Prayer of the Mem], by Jedaiah ben

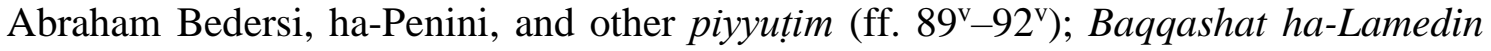
[Prayer of the Lamed], by Abraham ben Isaac Bedersi (ff. 92v-93v); Elef Alefin [Thousand Alef-s], by Jedaiah ben Abraham Bedersi, ha-Penini, and an assortment of other short poems (ff. $93^{\mathrm{v}}-95^{\mathrm{v}}$ ), Behinat 'Olam [Examination of the World], by Jedaiah ben Abraham Bedersi, ha-Penini (ff. $96^{\mathrm{r}}-98^{\mathrm{v}}$ ).

\footnotetext{
${ }^{9}$ N. Allony N. and E. (F.) Kupfer, List of Photocopies in the Institute. Part II, Hebrew Manuscripts in the Libraries of Belgium, Denmark, the Netherlands, Spain and Switzerland (Jerusalem 1964), p. 95.

${ }^{10}$ J. Llamas, 'Los manuscritos hebreos de la Real Biblioteca de San Lorenzo de El Escorial', Sefarad, 3, no. 1 (1943), p. 57.

${ }^{11}$ J. del Barco, Catálogo de manuscritos hebreos de la Comunidad de Madrid (Madrid 2003-6), vol. 3, p. 195.

${ }^{12}$ [http://aleph.nli.org.il/F/GYBFE5K4HTY4NQ29E8SL7RYA6VYCXL4NA2I88SBQV8I5P1131N11927?func=full-set-set\&set_number $=007860 \&$ set_entry=000011\&format=999] (last accessed on 8/6/2018).

${ }^{13}$ First reference to the edition, with all three works listed, but no further discussion, appeared in E. Alfonso, 'Miscelánea literaria y exegética', in: E. Alfonso et al., Biblias de Sefarad/Bibles of Sepharad (Madrid 2012), p. 344.
} 
The texts in ff. $215^{\mathrm{r}}$ to $279^{\mathrm{v}}$, in contrast, are of an exegetical nature: fragments of opinions and commentaries taken from works by Maimonides, Gersonides, Naḥmanides, Nathan ben Joel Falaquera and other authors (ff. $215^{\mathrm{r}}-222^{\mathrm{r}}$ ); commentary on the Song of Songs, by Gersonides (ff. $223^{\mathrm{r}}-255^{\mathrm{r}}$ [ $=$ ff. $223^{\mathrm{r}}-237^{\mathrm{r}}$ bis]); ${ }^{14}$ beginning of commentary on Ecclesiastes, by Gersonides (ff. $255^{\mathrm{v}}-259^{\mathrm{v}}$ [= ff. $237^{\mathrm{v}}$ bis $-241^{\mathrm{v}}$ bis]); and commentary on the Song of Songs and Ruth (ff. $260^{\mathrm{r}}-279^{\mathrm{v}}$ [ $=$ ff. $242^{\mathrm{r}}$ bis $-261^{\mathrm{v}}$ bis]).

The provenance of the codex is unknown, and the date and circumstances of its arrival at the RBSLE are likewise uncertain. On the verso of the initial flyleaf there are three old bookshelf numbers: iij E 19, G-IV-4 (both crossed out) and Num ${ }^{\circ} 55 .{ }^{15}$ The codex was not rebound in the RBSLE ${ }^{16}$ and retains a binding that seems Spanish and that most probably dates from the fourth quarter of the sixteenth century, possibly even the beginning of the seventeenth. ${ }^{17}$

\footnotetext{
${ }^{14}$ On this foliation, see above, n. 8.

${ }^{15}$ In addition there is an annotation: '98 hoj. mss. 78 impresas', and the current bookshelf number. According to J. L. del Valle-Merino, RBSLE's director, no detailed studies have been done of the older bookshelf numbers used between the sixteenth and the nineteenth centuries for ordering the collections. Thus, it is impossible here to give exact dates for the use of each of these numbers, which applies as well to the volume containing the copies from Soncino. In his study on the provenance of Hebrew codices held at the RBSLE, De Andrés ('Historia de las procedencias de los códices hebreos de la Real Biblioteca de El Escorial', Sefarad, 30, no. 1 [1970], p. 9) identifies, with a question mark, MS G-IV-5 with one of the manuscripts listed in RBSLE, MS K. I. 19, ff. 281-283v, featuring all the Hebrew codices owned by the librarian Benito Arias Montano that entered the library's holdings when he died in 1598. The entry (no. 24 in the list) reads as follows: 'Libro llamado Beresit Raba, glosador sobre el principio de la creación de Adán y Eva, en cuarto' [Book called Bereshit Rabbah, which comments on the beginnings of the creation of Adam and Eve; in cuarto]. This identification was proved wrong by Pérez Castro ('Los códices hebreos de la Biblioteca de El Escorial y sus antiguos inventarios,' Sefarad, 32 [1972], p. 158). Del Barco (op. cit. [n. 11], vol. 3, p. 195), notes seventeenth century, also with a question mark. For a recent study on the provenance of the Real Biblioteca's collection, see M.T. Ortega-Monasterio, 'The History and Formation of Hebrew Manuscript Collection in Spain', in: E. Alfonso et al., op. cit. (n. 13), pp. 149-75. On the change of bookshelf numbers, see ibid., pp. 158-9.

${ }^{16}$ On the binding of books at the Real Biblioteca, see V. Nieto Alcaide, 'Felipe II y la imagen del libro. Las encuadernaciones y la Biblioteca de El Escorial', Reales sitios: Revista de Patrimonio Nacional, 135 (1998), pp. 46-55.

${ }^{17}$ See N. Pickwoad, 'Books for Reading: Commercial Bindings in Parchment and Paper in the Era of the Handpress', Great Bindings from the Spanish Royal Collections: 15th-21st Centuries (Madrid 2012), pp. 106-7. We are very grateful to N. Pickwoad, who kindly examined various pictures of the binding and sent us a detailed technical description. The hypothesis about the binding's provenance and dating, based on this examination, is his.
} 
The right cover features a now illegible line written in Hebrew on parchment which presumably identified either the owner of the codex or its contents.

\section{The incunabula from Soncino}

The three incunabula at the RBSLE that were printed in Soncino between 1484 and 1485 are bound together in one volume, with bookshelf number $83-$ VII-23 in the collection of Hebrew printed materials. The eighteenth-century binding, made in El Escorial, probably replaces an earlier one. ${ }^{18}$

\section{a) The book and its contents}

The book includes the following incunabula, in this order:

(1) Perush Mishnat Avot [Commentary on the Tractate 'Fathers'], with the introduction Shemonah Peraqim [Eight Chapters], by Moses Maimonides. Translated from Arabic by Samuel ben Judah ibn Tibbon. [Soncino: Joshua Solomon Soncino, about 1484-5].

The book is described in: Benjacob, פ 1172; BHB, 000151124; Bod-inc, Heb 64; BSB-Ink, M-411; Catane, 10; Chwolson, 901; Cowley, p. 444; De Rossi, II, XIX; Fr., 41; Friedberg, 34 [ה]; Friedberg, BES, מ 4095, 1; Goff, Heb-83; Goldstein, 35; GW, M23783; H, 13011; Habermann, Soncino, p. 20, 4; Iakerson, Inkunabuly, 45-47; Iakerson, IVAN, 42; Iakerson, JTS, 24; Iakerson, OH, 34; IDL, 2461; IGI, 2436 = VI E47; ISTC, im00624800; ${ }^{19}$ Madsen, 4263; Manzoni, 5; Markon; Marx, 46; Meyer, 43; Meyer and Sáenz Badillos, 57; Offenberg, BMC, p. 32; Offenberg, Census, 93; Ohly and Sack, 2010; Pr., 7295; Da Silva Rosa, 4; Schwab, 29; St.CB, 1433, 1; STCItaly, p. 441; Striedl, p. 8; TamaniParma, 45; TamaniPiacenza, 24; TamaniSoncino, 12; Thes, A

\footnotetext{
${ }^{18}$ See M.T. Ortega-Monasterio, 'Las bibliotecas y sus manuscritos hebreos', in: J. del Barco, op. cit. (n. 11), vol. 1, pp. 52-3. Numerous codices affected by the 1671 fire were bound in the eighteenth century. ${ }^{19}$ We have already reported to ISTC the existence of this copy from Soncino.
} 
41; TishbyIsr, 50; TishbyVat, 22; Van Straalen, p. 169; VB, 3583; Vinograd, 2; Wiener, Introd.; Zedner, p. 550; Zehnacker, 1603.

For a complete, comprehensive description of the edition, see Iakerson, JTS, 24, and Offenberg, BMC, p. 32. For a complete list of libraries holding copies of this incunabulum, see ISTC, im00624800, and Offenberg, Census, 93.

(2) Behinat 'Olam [Examination of the World], by Jedaiah ben Abraham Bedersi, haPenini, with anonymous commentary. Soncino: [Joshua Solomon Soncino], 12 December 1484.

The book is described in: Adler, 38; Arnoult, 890; Benjacob, ב 232; BHB, 000138544; Bod-inc, Heb 48; Burger, 126; Cassuto, 9; Catane, 10; Chwolson, 154; CIBN, Heb-32; Cowley, p. 311; De Rossi, I, X; Fr., 27; Friedberg, 24 [7]; Friedberg, BES, ב 341, 2; Goff, Heb-61; Goldstein, 27; GW, M11898; H, 9368; Habermann, Soncino, p. 20, 5; Iakerson, Inkunabuly, 23-26; Iakerson, IVAN, 46, 47; Iakerson, JTS, 23; Iakerson, OH, 14; IBH, 1880; IDL, 2455; IGI, 5101 = VI E83; ISTC, ij00218530; ${ }^{20}$ Kiselev, 361; Madsen, 4315; Manzoni, 4; Markon; Marx, 33; Meyer, 33; Meyer and Sáenz Badillos, 139; Oates, 2716; Offenberg, BMC, p. 31; Offenberg, Census, 76; Offenberg, Rosent., 6; Ohly and Sack, 1600, 1601; PolainB, 4059; Pr., 7294; Roest, 534; Schwab, 28; St.CB, 5670, 2; STCItaly, p. 346; TamaniParma, 77;

TamaniSoncino, 4; Thes, A 30; TishbyIsr, 12; TishbyVat, 4; VB, 3582; Vinograd, 8; Walsh, Harvard, Heb 8; Wiener, 1102; Yerusalimsky, 12; Zaccaria, p. 21; Zedner, p. 314; Zehnacker, 2436.

\footnotetext{
${ }^{20}$ We have already reported to ISTC the existence of this copy from Soncino.
} 
For a complete, comprehensive description of the edition, see Iakerson, JTS, 23, and Offenberg, BMC, p. 31. For a complete list of libraries holding copies of this incunabulum, see ISTC, ij00218530, and Offenberg, Census, 76.

(3) Mivhar ha-Peninim [Selection of Pearls], attributed to Solomon ibn Gabirol, translated from Arabic by Judah ben Saul ibn Tibbon, with anonymous commentary. ${ }^{21}$ [Soncino]: Joshua Solomon Soncino, [corrected by Solomon ben Peretz Bonfoi Tzarfati], 14 January 1484.

The book is described in: Adler, 37; Benjacob, s 329; BHB, 000105929; Bodinc, Heb 74; BSB-Ink, S-249; Burger, 125; Cassuto, 8 bis; Catane, 9; Cat MMW, 172; Chwolson, 648; CIBN, Heb-29; CohenYeshiva, 11; Cowley, p. 650; Davidson, ש 2063; De Rossi, I, IX; Fr., 53; Friedberg, 23 [ג]; Friedberg, BES, מ 353, 1; Goff, Heb-98; Goldstein, 25; GW, M41205; H, 9369 = 11136; Habermann, Soncino, p. 18, 2; Iakerson, Inkunabuly, 20-22; Iakerson, IVAN, 3, 4; Iakerson, JTS, 21; Iakerson, Selected Pearls, 25; IBP, 5063; IDL, 2449; IGI, 8567 = 3403 = 5099 = VI E65; ISTC, is00625250; ${ }^{22}$ Kiselev, 595; Madsen, 4333; Manzoni, 3; Markon; Martín Abad, S-114; Marx, 59; Meyer, 29; Meyer and Sáenz Badillos, 121; Oates, 2715; Offenberg, BMC, p. 28; Offenberg, Census, 57; Offenberg, Rosent., 5; Ohly and Sack, 2543, 2544; Polain, 10387 (10150); Pr., 7293; Roest, 1002; Schwab, 27; St.CB, 6916, 1; STCItaly, p. 436; Striedl, p. 8; TamaniParma, 61; TamaniSoncino, 2; Thes, A 27; Thishby, 30; TishbyIsr, 56; TishbyVat, 28; VB, 3581; Vinograd, 3; Wach., 264; Walsh, Harvard, Heb 7; Wiener, Introd.; Yerusalimsky, 33; Zaccaria, pp. 20-21; Zedner, p. 537; Zehnacker, 2058.

\footnotetext{
${ }^{21}$ Sh. Iakerson, Catalogue of the Hebrew Incunabula from the Collection of the Library of the Jewish Theological Seminary of America, (New York and Jerusalem 2004), vol. 1, no. 21, suggests Samson Munay as the author of the commentary with a question mark.

${ }^{22}$ We have already reported to ISTC the existence of this copy from Soncino.
} 
For a complete, comprehensive description of the edition, see Iakerson, JTS, 21, and Offenberg, BMC, p. 28. For a complete list of libraries holding copies of this incunabulum, see ISTC, is00625250, and Offenberg, Census, 57.

Maimonides (1135-1240) wrote a long introduction to his commentary on Avot [Fathers] known as Shemonah Peraqim, which is actually a short treatise on ethics inspired by Aristotle that would become a classic of Jewish ethics. Behinat 'Olam is the most famous work of Jedaiah ben Abraham Bedersi (c. 1280-c. 1340), in which the author addresses one of the most traditional ethical tropes in the Bible, the vanity and futility of this world. ${ }^{23}$ The collection of epigrams, Mivhar ha-Peninim, also deals mainly with ethical issues taken from Islamic ethical literature. Traditionally attributed to Solomon ibn Gabirol (c. 1021-c. 1057), some editions have suggested Jedaiah ben Abraham Bedersi as author. There is no conclusive evidence for any of these attributions. ${ }^{24}$

That these three copies were gathered into a single volume is easily explained by the fact that they all came off Joshua Solomon Soncino's press between 1484 and 1485 . Nonetheless, it is equally clear that the three works are linked by their content: all of them are ethical-philosophical texts. For both of these reasons, we cannot discard the possibility that the three editions were already bound together in a single volume even before they arrived at El Escorial at the end of the sixteenth century.

\section{b) Special characteristics of the RBSLE copies}

Perush Mishnat Avot is lacking the first folio in the first quire, which was blank, therefore the text is not faulty:

\footnotetext{
${ }^{23}$ A manuscript copy of this work can be found in MS G-IV-5, in which is inserted the incunabulum from Leiria that is analyzed in the section above.

${ }^{24}$ J. Dan, 'Mivhar Ha-Peninim', in: M. Berenbaum and F. Skolnik, op. cit. (n. 3), vol. 14, pp. 372-3.
} 
Collation: $1^{8-1}$ (without 1.1 , blank) $2-6^{8} .47$ leaves.

Mivhar ha-Peninim is lacking the first folio in the first quire - which was blank, as in the first incunabulum - and the last folio in the last quire, with the end of the colophon:

Collation: $1^{8-1}$ (without 1.1 , blank) $2-7^{8} 8^{4-1}$ (without 8.4 ). 58 leaves.

Behinat 'Olam is perfect. All three copies are in excellent condition, and bear no traces of either expurgation or censorship. The first and third incunabula in the volume Perush Mishnat Avot, and Mivhar ha-Peninim - have no traces of use. Only the second incunabulum, that is, Behinat 'Olam, does show some marginal annotations in Hebrew, including corrections on the printed text, thus proving that it was read by a Jewish owner before it arrived at El Escorial. The other two copies bear no traces of either marginal annotations or corrections.

\section{c) RBSLE, 83-VII-23}

The three incunabula were bound in one single book. Three flyleaves at the beginning and three at the end were added with the current binding. ${ }^{25}$ One additional flyleaf has been added at the beginning, before the first incunabulum. ${ }^{26}$ On the verso of this additional flyleaf there are several older bookshelf numbers: א.Z.37 (crossed out); IV.Bis (with the 'I' added later in a different ink); ij.I.27 (crossed out, with the 'I' in a box, below which is written 'oc.'); and iij.G.7. On folio $\left[1^{\mathrm{a}}\right]$ of the first incunabulum, there is the bookshelf number AB.or/rlij.83, in addition to the current one, 83-VII-23, in

\footnotetext{
${ }^{25}$ These are in fact two bifolia at the beginning and two at the end, the folio next to the cover being glued to the inside cover.

${ }^{26}$ This flyleaf probably belonged to the previous binding, and was included here because of the older bookshelf numbers and annotations it exhibits; see below. This flyleaf could not possibly be the first, blank folio of the first quire of Perush Mishnat Avot, as the type of paper of the flyleaf is completely different from that used in the incunabulum.
} 
red pencil. The volume has gilt edges, and on them is written ' 27 ', later corrected to '37' and, below, '7'. These three numbers refer to the book's shelving order on the shelves where it was found under the bookshelf numbers ij.I.27, x.Z.37, y iij.G.7, respectively, with the first being the oldest, and the last the most modern of the three.

Also on the verso of the additional flyleaf are other annotations referring to the content, probably written by different librarians, the longest of which is titled 'Expositio super traditiones [above this word: "misna"] Patrum Authore R. Moyse ben [written above this word: "filij"] maymon'. This doubtless refers to the first of the works included in the volume, the commentary on Avot by Maimonides. On folio [1 $\left.1^{\mathrm{a}}\right]$ of the first incunabulum the annotation 'Rab. Samuel', which has been crossed out, refers to the Hebrew translator of Maimonides's commentary, Samuel ibn Tibbon (c. 11651232), who is referred to at the beginning of the prologue with the formula אמר שמואל בן יהודה אבן תבון. On this same page is written 'pre cep', 'E' (?), and '1', the last of which signifies that the work by Maimonides is the first in the volume. This is also the meaning of the number ' $10-1$ ' that is found on the verso of the additional flyleaf, although it is uncertain what the '10' refers to. The annotations 'Rab. Samuel' and 'pre cep' are key to understanding another annotation that we find on the edges, 'Pre. SAMVEL.' which should be interpreted as 'precepta Samuelis'.

Of special interest is the Hebrew annotation written on the recto of the additional flyleaf: מכרתי זה נאום קלונימוס הלוי. Although it is common for an owner to leave proof of his purchase of a book with the formula קניתי זה הספר, it is far less common for a seller to note the sale of a book, since by that act he ceases to be the book's owner. In this case, it is impossible to know if the person who sold the book was its owner or a bookseller. In addition, the presence of this Hebrew annotation suggests that the additional flyleaf belonged to a previous binding, which also included the three 
incunabula present in this volume, before it arrived to El Escorial. Indeed, this Hebrew annotation is the only one in the volume that documents a sale transaction before the book's arrival at El Escorial.

On folio $\left[1^{\mathrm{a}}\right]$ of Behinat 'Olam, we find ' $10-2$ ' and the number ' 2 ', which indicate that this work is the second one in the volume. They are thus related to the already mentioned bookshelf numbers ' $10-1$ ' and the ' $10-3$ ' that can be found on folio [1 $\left.1^{\mathrm{a}}\right]$ of Mivhar ha-Peninim, the third work in the volume.

Although the three works were printed in Italy, we are not able to assert with confidence that they were bought there in order to be sent to El Escorial. We know that Benito Arias Montano made numerous book purchases both in Italy and in the Low Countries, at times on the king's behalf and at times on his own initiative, and therefore he may have acquired the volume there. ${ }^{27}$ But in the absence of more solid evidence, this possibility must remain a hypothesis.

\section{Some additional notes on the incunabulum from Híjar at the Archivo Histórico}

\section{Nacional}

The fragments of the Hebrew incunabulum from Hijar in the Archivo Histórico Nacional were come upon by Ignacio Panizo-Santos, former archivist of the Inquisition Section, and their discovery was first announced in $2010 .{ }^{28}$ They belong to the edition of the Hebrew Bible printed between 1487 and 1488 by Eliezer ben Abraham Alantansi in Híjar (Aragon), which contains the Pentateuch with haftarot and five megillot. All of the fragments were used in the sixteenth century as concertina guards or reinforcing flaps for Inquisition files from the Calahorra-Logroño court. The reason why additional

\footnotetext{
${ }^{27}$ See Ortega-Monasterio, op. cit. (n. 18), pp. 42-3.

${ }^{28} \mathrm{~J}$. del Barco and I. Panizo-Santos, 'Fragmentos de incunables hebreos en documentos inquisitoriales del Tribunal de Calahorra-Logroño’, Huarte de San Juan. Geografía e Historia, 17 (2010), pp. 295-308.
} 
details about their identification are presented here is that there were doubts initially as to whether all the fragments belonged to the same edition of the Bible ${ }^{29}$ however, we have finally confirmed that they did come from the same edition, ${ }^{30}$ and we can thus provide a definitive description of them here:

Pentateuch, Haftarot [Prophetic Readings], Five Megillot [Scrolls]. [Híjar: Eliezer ben Abraham Alantansi, between 1487-8].

The book is described in: Adler, 5; BHB, 000312542; Bod-inc, Heb 14; CIBN, Heb-5; Cowley, p. 75; Davidson, x 6788; De Rossi, II, XXVII; Freimann, Perg., 20; Friedberg, 98 [7]; Friedberg, BES, ת 637, 2; Goff, Heb-14; Goldfeld, 14; Goldstein, 88; GW, M30628; H, 12571; Haebler, 531; Iakerson, JTS, 95; IGI, 7395 = VI E9; IBE, 6213; ISTC, ib00525600; Martín Abad, B-114; Marx, 8; Meyer, 227; Meyer and Sáenz Badillos, 16; Offenberg, Census, 15; Pr., 9601; Schwab, 64; St.CB, $1011+$ a; TamaniParma, 10; TamaniPiacenza, 5; Thes, B 12; TishbyIsr, 78; Vindel, IV, 345:4; Vinograd, 5; Wach., 70; Weiser, 10; Yaari, Marks; Zafren, Bible, 27.

For a complete, comprehensive description of the edition, see Iakerson, JTS, 95. For a complete list of libraries holding copies of this incunabulum, see ISTC, ib00525600, and Offenberg, Census, 15.

This copy:

$4^{\text {o }} .1$ complete folio (frag. A), and 3 other fragments (frags. B, C, and D) from different folios each.

\footnotetext{
${ }^{29}$ Del Barco and Panizo-Santos, op. cit. (n. 28), pp. 306-7.

${ }^{30}$ All fragments have been confronted against catalogue descriptions and digitized images of the JNUL copy of Alantansis's edition of this Bible, accessible from the JNUL online bibliographic description at [http://aleph.nli.org.il:80/F/?func=direct\&doc number=002094150\&local base=NNLALL] (last accessed on $8 / 6 / 2018$ ).
} 
Frag. Aa Beginning: ויתלו את המן על האץ אשר

Frag. Ab. End: ושאר היהודים אשר במדינות המלך

Frag. Ba . Beginning: יהע]

Frag. B ${ }^{b}$. End: עשר יומא

Frag, Ca . Beginning: שנעת חי יהוה באמת]

Frag. Cb. End: שמי[ם וימתחם כאהל [לש] [בת]

קצה גבולך [נעברה] נא :Frag. Da . Beginning

Frag. D' End: ויפנו ויעלו דרך הבשן

Frag. A (complete fol.) $)^{\text {a: }} 2$ cols., 27 lines, 175 x $135 \mathrm{~mm}$, intercol. $14 \mathrm{~mm}$.

Types: Square, without vocalization or accents (these have been added later with ink). In fragment C, headline of parashat אלה הדברים in large square characters placed in the space of two lines. ${ }^{31}$

No foliation. No signatures. Heading in frag. $C^{b}$. No catchwords.

Parchment, frag. A: 265 x 185 mm.; frag. B: 247 x 43 mm.; frag. C: 235 x 60 mm.; frag. D: 255 x $25 \mathrm{~mm}$.

Contents:

Frag. A Esther 7:10 to 9:16 (=f. 189 in JNUL copy).

Frag. B Joshua 5:2-10 (part of the haftarah for the first day of Pesah, Joshua 5:2-15) with Targum Jonathan, verse by verse $^{32}$ (= outer columns in f. 163 of JNUL copy).

\footnotetext{
${ }^{31}$ Iakerson, op. cit. (n. 21), no. 95, identifies the types as follows: Haebler, Híjar, 1. 2. 117/8 quadr. (square type for the biblical text); Haebler, Hijar, 1. 4. 230 quadr. (large square type for headlines). ${ }^{32}$ Although the practice of including the Aramaic version of the Targum in the haftarot for Pesah and Shavuot is distinctly Ashkenazi, it would not be so strange to see this practice reflected in the first
} 
haftarah for parashat מטות-מסעי and the beginning of the haftarah for parashat דברים) and Isaiah 40:9-22 (verso, from the haftarah for parashat ואתחנן) (= inner columns in f. 156 of JNUL copy).

Frag. D Numbers 20:16-28 (recto) and Numbers 21:26-33 (verso) (= inner columns in f. 98 of JNUL copy).

In fragment A, some damages, especially in the inner columns, have been restored with paper. Fragment A has been detached from the Inquisition file where it was reused as guard. The other three fragments are still sewed to Inquisition files, serving as reinforcing flaps.

Madrid, Archivo Histórico Nacional, Inquisición 1677 Exp.2 (frag. A); Inquisición L.843 (frag. B); Inquisición 1669 Exp.4 (frag. C); and Inquisición 1665 Exp.3 (frag. D).

\section{Hebrew incunabula in Spanish libraries: An updated census}

The identification of the copies just described is significant within the context of Spain given the scarcity of extant Hebrew incunabula in Spanish libraries and archives. Among these, there are no other copies of the incunabulum from Leiria and, with

editions of Hebrew Bibles in the Iberian Peninsula, since the printing press and some of the first printing masters came from Central Europe. Another Ashkenazi practice, the inclusion of the Aramaic version of the Targum Onkelos and the commentary by Rashi - Solomon ben Isaac de Troyes, 1040-1105 - together with the Pentateuch, which was very rare in Sephardic manuscript production, is also attested in some incunabula editions of the Bible printed in the Iberian Peninsula, such as those from Híjar (1490) and Lisbon (1491); see Sh. Iakerson, 'Los primeros impresos hebreos de Sefarad (ca. 1475-1497?)', in: E. Alfonso et al., op. cit [n. 13], nos. 20 and 27, pp. 141-2. 
respect to incunabula from Soncino, only one other copy of the Soncino Mivhar haPeninim is preserved in the Biblioteca Nacional de España.

With the addition of these four new incunabula, the number of copies of Hebrew incunabula in Spanish archives and libraries has increased, for the time being, to eighteen, which correspond to sixteen different editions preserved in six different archives and libraries from twelve places of printing:

\section{BOLOGNA}

Pentateuch with Rashi’s Commentary. Bologna: Abraham ben Hayyim, for Joseph Caravita, 26 January 1482; f .

Goff, Heb-18; GW, M30624; Iakerson, JTS, 19; IBE, 999; ISTC, ib00525570; Martín Abad, B-113; Offenberg, BMC, 26 \& pl. p.147; Offenberg, Census, 13.

Madrid, Biblioteca Nacional de España (parchment).

\section{BRESCIA}

Pentateuch, Prophets, Hagiographa. Brescia: Gershom Soncino, 24-31 May 1494; $8^{\circ}$.

Goff, Heb-10; GW, 4200; Iakerson, JTS, 70; IBE, 1001; ISTC, ib00525540; Offenberg, BMC, 73; Offenberg, Census, 12.

Toledo, Biblioteca Pública del Estado.

\section{FERRARA}

Levi ben Gershom, Commentary on Job. [Ferrara]: Abraham ben Hayyim, 17 May $1477 ; 8^{\circ}$. 
CCPB, 000111269-4; Goff, Heb-70; GW, M18048; Iakerson, JTS, 17; IBE, 3495;

ISTC, il00189750; Offenberg, BMC, 23 \& pl. p.143; Offenberg, Census, 51.

Toledo, Biblioteca Pública del Estado.

\section{GUADALAJARA}

Jacob ben Asher, Yoreh De'ah [Guide of Knowledge]. [Guadalajara: Solomon Alkabetz, c. 1480]; f .

CCPB, 000110314-8; Goff, Heb-57; GW, M1039210; Iakerson, JTS, 82; IBE, 6251; ISTC, ij00000750; Offenberg, Census, 71.

San Lorenzo de El Escorial, Real Biblioteca (imperfect). ${ }^{33}$

\section{HIJAR}

Pentateuch, Haftarot [Prophetic Readings], Five Megillot [Scrolls]. [Híjar: Eliezer ben Abraham Alantansi, 1487-8]; $4^{\circ}$.

Goff, Heb-14; GW, M30628; Iakerson, JTS, 95; IBE, 6213; ISTC, ib00525600; Martín Abad, B-114; Offenberg, Census, 15.

Madrid, Archivo Histórico Nacional (1 folio and 3 fragments, parchment). ---, Biblioteca Nacional de España (imperfect, parchment). ${ }^{34}$

\footnotetext{
${ }^{33}$ Copy identified by C. del Valle, 'Dos nuevos incunables hebreos españoles y su censo,' Sefarad, 51 (1991): 199-202. This copy contains ownership annotations by Samuel ibn Nahmias, probably David ibn Nahmias's son rather than brother, since he has added, after his name, the epithet הצעיר, 'the younger'. Following their expulsion from Spain, the brothers David and Samuel ibn Nahmias were the printers of the first Hebrew book and the only incunabulum printed in Istanbul, Jacob ben Asher's Arba 'ah Turim (Constantinople: David and Samuel ibn Nahmias, 1493).

${ }^{34}$ This copy was identified by C. del Valle, op. cit. (n. 33). It has been digitized and uploaded to the Biblioteca Digital Hispánica: [http://bdh-rd.bne.es/viewer.vm?id=0000181045\&page=1] (last accessed on $8 / 6 / 2018)$.
} 
Jacob ben Asher, Yoreh De'ah [Guide of Knowledge]. Híjar: Eliezer ben Abraham Alantansi, $1487 ; \mathrm{f}^{\mathrm{o}}$.

Goff, Heb-56; GW, M10397; Iakerson, JTS, 94; ISTC, ij00000700; Martín Abad, J-2; Offenberg, BMC, 87; Offenberg, Census, 72.

Madrid, Biblioteca Nacional de España (97 leaves).

\section{LEIRIA}

Jeshua ben Joseph Halevi, Sefer Halikhot 'Olam [Methodology of the Talmud], with Sefer ha-Yir'ah [Book of Religious Fear], by Jonah Gerondi, and Sod ha-Teshuvah [Secret of Repentance], by Jonah Gerondi. [Leiria: Samuel Dortas, 1492-6]; 4 .

Goff, Heb-63; GW, M11941; Iakerson, JTS, 108; ISTC, ij00219500; Offenberg, BMC, 103; Offenberg, Census, 78.

San Lorenzo de El Escorial, Real Biblioteca.

Jacob ben Asher, Orah Hayyim [Path of Life]. [Leiria: Samuel Dortas], 2 June 1495; fo. CCPB, 000110315-6; Goff, Heb-53; GW, M10408; Iakerson, JTS, 107; IBE, 3080; ISTC, ij00000550; Offenberg, BMC, 103; Offenberg, Census, 68.

Valladolid, Biblioteca Universitaria.

\section{LISBON}


Pentateuch with Targum Onkelos and Rashi's Commentary. Lisbon: [Eliezer Toledano], between 8 July and 6 August 1491; $\mathrm{f}^{\mathrm{o}}$.

Goff, Heb-20; GW, M30638; Iakerson, JTS, 102; IBE, 1000; ISTC, ib00525640; Offenberg, BMC, 97 \& pl. p.243; Offenberg, Census, 17.

San Lorenzo de El Escorial, Real Biblioteca (imperfect, Leviticus to Deuteronomy).

\section{MANTUA}

Joseph ben Gurion, Yosippon. [Mantua]: Abraham Conat, 11 May [1475]; $4^{\circ}$.

CCPB, 000110563-9; Goff, Heb-65; GW, M15132; Iakerson, JTS, 14; IBE, 3322;

ISTC, ij00479900; Martín Abad, J-86; Offenberg, BMC, 16; Offenberg, Census, 79.

Madrid, Biblioteca Nacional de España.

\section{NAPLES}

Pentateuch, Prophets, Hagiographa. [Naples: Joshua Solomon Soncino, c. 1492]; $\mathrm{f}^{\mathrm{o}}$.

Goff, Heb-9; GW, 4199; Iakerson, JTS, 61; IBE (Add.), 6303; ISTC, ib00525520;

Offenberg, BMC, 61 \& pl. pp.199, 201; Offenberg, Census, 11.

Montserrat, Biblioteca de la Abadía (imperfect, Isaiah to Chronicles).

\section{PIOVE DI SACCO}

Jacob ben Asher, Arba' ah Turim [Four Pillars]. Piove di Sacco: Meshullam Cuzi, 3 July $1475 ; \mathrm{f}^{\mathrm{o}}$. 
CCPB, 000110314-8; Goff, Heb-47; GW, M10386; Iakerson, JTS, 10; IBE, 3079;

ISTC, ij00000200; Martín Abad, J-1; Offenberg, BMC, 20 \& pl. pp.133, 135;

Offenberg, Census, 61.

Madrid, Biblioteca Nacional de España (imperfect).

\section{ROME}

Moses ben Nahman, Commentary on the Pentateuch. [Rome: Obadiah, Manasseh and Benjamin of Rome, 1469-73]; f .

CCPB, 000111269-4; Goff, Heb-86; GW, M25518; Iakerson, JTS, 1; IBE, 4034; ISTC, im00866140; Offenberg, BMC, 8 \& pl. p.119; Offenberg, Census, 96.

Montserrat, Biblioteca de la Abadía (imperfect).

\section{SONCINO}

Solomon ibn Gabirol (attr.), Mivhar ha-Peninim [Selection of Pearls], translated from Arabic by Judah ben Saul ibn Tibbon, with anonymous commentary. [Soncino]: Joshua Solomon Soncino, 14 January 1484; $4^{\circ}$.

Goff, Heb-98; GW, M41205; Iakerson, JTS, 21; ISTC, is00625250; Martín Abad, S114. Offenberg, BMC, 28; Offenberg, Census, 57.

Madrid, Biblioteca Nacional de España.

San Lorenzo de El Escorial, Real Biblioteca (imperfect). 
Jedaiah ben Abraham Bedersi, ha-Penini, Behinat 'Olam [Examination of the World], with anonymous commentary. Soncino: [Joshua Solomon Soncino], 12 December 1484; $4^{\circ}$.

Goff, Heb-61; GW, M11898; Iakerson, JTS, 23; ISTC, ij00218530; Offenberg, BMC, 31; Offenberg, Census, 76.

San Lorenzo de El Escorial, Real Biblioteca.

Moses Maimonides, Perush Mishnat Avot [Commentary on the Tractate 'Fathers'], with the introduction Shemonah Peraqim [Eight Chapters]. Translated from Arabic by Samuel ben Judah ibn Tibbon. [Soncino: Joshua Solomon Soncino, 1484-5]; 4

Goff, Heb-83; GW, M23783; Iakerson, JTS, 24; ISTC, im00624800; Offenberg, BMC, 32; Offenberg, Census, 93.

San Lorenzo de El Escorial, Real Biblioteca.

\section{Abbreviations}

Adler $=$ Adler, I. 'Les incunables hébraïques de la Bibliothèque Nationale'. In Le livre hébraïque. Incunables, publications israéliennes. Exposition organisée avec le concours de la Bibliothèque Nationale. Edited by Services culturels, Embassade d'Israël, pp. 65-119. Paris 1962.

Amzalak, M. B. A tipografia hebraica em Portugal no século quinze. Coimbra 1922. Anselmo = Anselmo, A. Origens da imprensa em Portugal. Lisboa 1981. 
Arnoult $=$ Arnoult, J. -M. Catalogues régionaux des incunables des Bibliothèques publiques de France. Vol.I: Bibliothèques de la Région Champagne-Ardenne. Bordeaux 1979.

Benjacob = Benjacob, Y. A. Otzar ha-sefarim. Wilna 1876-80.

$\mathrm{BHB}=$ Bibliography of the Hebrew Book, The National Library of Israel. Online resource:

http://aleph.nli.org.i1/F/TJETMCESRDQIGCR8YCPA1T3KUPVNDJB7XPTQ8 $\underline{\text { KYK3VAHFF6KLY-13509?func=find-b-0. }}$

BiblPort = Bibliografia geral portuguesa. Vol. 1. Lisbon 1940.

Bod-inc $=$ Coates, A. et al. A Catalogue of Books Printed in the Fifteenth Century now in the Bodleian Library. 6 vols. Oxford 2005. Online resource: http://incunables.bodleian.ox.ac.uk/.

Briquet = Briquet, Ch.-M. Les filigranes. Dictionnaire historique des marques $d u$ papier dès leur apparition vers 1282 jusqu'en 1600.- A facsimile of the 1907 edition with supplementary material contributed by a number of scholars. 4 vols. Edited by A. Stevenson. Amsterdam 1968.

BSB-Ink = Bayerische Staatsbibliothek Inkunabelkatalog. Bd. 1-6. Wiesbaden 1988-2005.

Burger $=$ Burger, C. P., Jr. De incunabelen en de Nederlandse uitgaven tot 1540 in de Bibliotheek del Universiteit van Amsterdam. Vol. 2. 's-Gravenhage 1923.

Cassuto = Cassuto, U. 'Incunabuli ebraici a Firenze'. La Bibliofilia, 12 (1910/11), pp. 349-56, 464-72; 13 (1911/12), pp. 222-30, 384-94. Reprint. Firenze 1912.

Catane = Catane, M. Le livre hébraïque. Incunables et chefs d'oeuvre de l'imprimerie Strasbourgeoise di XVIe siècle, conservés par la Bibliothèque Nationale et Universitaire de Strasbourg. [Strasbourg, 1963]. 
CCPB = Catálogo Colectivo del Patrimonio Bibliográfico Español, Ministerio de Cultura y Deporte. Online resource: http://catalogos.mecd.es/CCPB/ccpbopac/.

Chwolson = Chwolson, D. Catalog der hebräischen Bücher in der Bibliothek des

Professors D. Chwolson [Hebrew]. Wilna 1897.

CIBN = Catalogue des incunables [de la] Bibliothèque nationale. Vol. 2, fasc. 4: S-Z et

Hebraica. Reprint. by U. Baurmeister e.a., Paris 1985.

CohenYeshiva $=$ Cohen, A. Hebrew Incunabula in the Mendel Gottesman Library of Hebraica-Judaica, Yeshiva University [Hebrew]. New York 1984.

Cowley = Cowley, A. E. A Concise Catalogue of the Hebrew Printed Books in the Bodleian Library. Oxford 1929.

Da Silva Rosa = Da Silva Rosa, J. S. David Montezinos, de stichter der 'Livraria D. Montezinos' (1 Thebet 5589-5674), pp. 6-7. Amsterdam 1914.

Davidson = Davidson, Y. Otzar ha-shirah ve-ha-piyyut. 4 vols. New York 1970.

De Rossi = De Rossi, J. B.. Annales hebraeo-typographici sec. XV. Parma 1795.

Fr. = Freimann, A. 'Die hebräischen Inkunabeln der Stadtbibliothek zu Frankfurt a. M'.

In Festgabe für Friedrich Clemens Ebrard zur Vollendung seines 70.

Lebensjahres..., pp.129-44. Frankfurt am Main 1920.

Freimann, Perg = Freimann, A. 'Die hebräischen Pergamentdrucke'. Zeitschrift für Hebräische Bibliographie, 15 (1911), pp. 46-57.

Freimann, Ink = Freimann, A. 'Über hebräische Inkunabeln'. Zentralblatt für Bibliothekswesen, 19 (1902), pp. 108-17.

Friedberg = Friedberg, B. History of Hebrew Typograpy in Italy, Spain-Portugal, Turkey and the Orient [Hebrew]. Antwerp 1934.

Friedberg, BES = 'Bet eqed sefarim': Bibliographical Lexikon of the whole Hebrew and Jewish-German Literature, Inclusive of the Arab, Greek, French-Provencal, 
Italian, Latin, Pegian, Samaritan, Spanish-Portuguese and Tatarian works, Printed in the Years 1474-1950 with Hebrew Letters. Tel Aviv 1951-6.

Goff = Goff, F. R. Incunabula in American Libraries: A Third Census of Fifteenth-

Century Books Recorded in North American Libraries. New York 1964. Reprint. Millwood, N.Y. 1973.

Goldfeld = Goldfeld, L. N. 'Hebrew Incunabula in the Casanatense Library in Rome' [Hebrew]. Yad la-kore', 18 (1949-50), pp. 223-40.

Goldstein $=$ Goldstein, D. Hebrew Incunables in the British Isles: A Preliminary

Census. London 1985.

GW = Gesamtkatalog der Wiegendrucke. Bd. I [etc.] Stuttgart, etc., 1968- [in progress]. (Vols. 1-7 reproduced with additions and corrections from the original edition, Leipzig, etc., 1925-38). Online resource, GW Manuskript - GW M: http://www.gesamtkatalogderwiegendrucke.de.

Habermann, Soncino = Habermann, A. M. Ha-madpisim bene Sontzino - Toledotehem ve-reshimat ha-sefarim ha-'ivriim she-nidpesu 'al yedehem. Wien 1933.

Haebler $=$ Haebler, K. Typenrepertorium der Wiegendrücke. Abt. IV (Ergänzband). Leipzig 1922. Reprint. Nendeln 1967.

Haebler, BI = Haebler, K. Bibliografía ibérica del siglo XV. 2 vols. La Haye-Leipzig 1903-17. Reprint. New York 1963.

$\mathrm{H}=$ Hain, L. Repertorium Bibliographicum in quo libri omnes ab arte typographica inventa usque ad annum MD. typis expressi ordine alphabetico vel simpliciter enumerantur vel adcuratius recensentur. 2 vols. Sttutgart-Paris 1826-38.

HSTC = A Short-Title Catalogue of the Hebrew Incunables and other Books Illustrated in the 'Thesaurus' with some Bibliographical References. Supplement to Part I 
of A. Freimann - M. Marx, Thesaurus Typographiae Hebraicae Saeculi XV. Jerusalem 1968.

Iakerson, Inkunabuly = Iakerson, S. M. Evreiskie inkunabuly. Opisanie exzempliarov hranjashihsja v bibliotekach Moskvy i Leningrada. Leningrad 1988.

Iakerson, IVAN = Iakerson, S. M. Katalog inkunabulov na drevneevreiskom iazike biblioteki Leningradskogo otdelenia Instituta vostokovedenia AN SSSR. Leningrad 1985.

Iakerson, JTS = Iakerson, S. M. Catalogue of Hebrew Incunabula from the Collection of the Library of the Jewish Theological Seminary of America. 2 vols. New York 2004-5.

Iakerson, $\mathrm{OH}=$ Iakerson, S. M. Ohel Hayyim: Catalogue of Hebrew Manuscripts in the Library of the Family of Menasseh Rafael and Sara Lehmann [Hebrew]. Vol. 3: Printed books. New York 1996.

Iakerson, Selected Pearls = Iakerson, S. M. Mivhar Peninim. Selected Pearls. Treasures of Jewish Culture in Saint-Petersburg (manuscripts, documents, incunabula, ritual objects). Saint-Petersburg 2003.

IBE = García Craviotto, F. (coord.). Biblioteca Nacional [Madrid]. Catálogo general de incunables en bibliotecas españolas. 2 vols. Madrid 1989-90. (Adiciones y correcciones. I-II, Madrid 1991-4).

$\mathrm{IBH}=$ Sajó, G. and E. Soltész. Catalogus incunabulorum quae in bibliothecis publicis Hungariae asservantur. 2 vols. Budapest 1970.

$\mathrm{IBP}=$ Bohonos, M., and E. Sandorowska. Incunabula quae in bibliothecis Poloniae asservantur. Moderante Alodia Kawecka-Gryczowa. 2 vols. Wrocław 1970. (Addenda, Indices. Wrocław 1993).

IDL = van Thienen, G. (ed.). Incunabula in Dutch libraries. 2 vols. Nieuwkoop 1983. 
IGI = Guarnaschelli, T. M. et al. (eds.). Indice generale degli incunaboli delle biblioteche d'Italia. 6 vols. Rome, 1943-81.

ISTC = Incunabula Short Title Catalogue, The British Library. Online resource: http://www.bl.uk/catalogues/istc/ and http://data.cerl.org/istc/.

Jacobs $=$ Jacobs, J. 'Check-List of Hebrew Incunabula'. In Jewish Encyclopedia . Edited by I. Singer. New York-London 1901-6, vol. 6, pp. 578-9.

Kiselev $=$ Kiselev, N. P. Inventar' inkunabulov vsesojuznoi Biblioteky imeni V. I. Lenina. Moscow 1939.

Madsen $=$ Madsen, V. Katalog over det Kongelige Bibliotheks inkunabler. 3 vols. Copenhagen 1935-63.

Manzoni = Manzoni, G. ספר גר-שם overo Annali tipografici dei Soncino, contenenti la descrizione e illustrazione delle stampe Ebraiche, Talmudiche, Rabbiniche, Greche, Latine ed Italiane ... Tom. 2, parte prima, tomo unico: a Soncino e a Casalmaggiore, (1493-1490). Bologna 1886. Reprint. Westmead, Farnborough, 1969.

Markon = Markon, J. 'Inkunabeln'. In Jüdisches Lexikon. Ein enzyklopädisches Handbuch des jüdischen Wissens in vier Bänden. Edited by G. Herlitz, and Bruno Kirschner. Berlin 1927-30.

Martín Abad = Martín Abad, J. Catálogo bibliográfico de la colección de incunables de la Biblioteca Nacional de España. 2 vols. Madrid 2010.

Marx = Marx, M. 'Catalogue of the Hebrew Books Printed in the Fifteenth Century now in the Library of the Hebrew Union College'. Studies in Bibliography and Booklore, 1 (1953), pp. 21-47.

Meyer = Meyer, H. M. A., and I. Mehlman. Supplement to Part I of the Facsimile Reproduction of the Thesaurus Typographiae Hebraicae Saeculi XV: Hebrew 
Printing during the Fifteenth Century Edited by A. Freimann and M. Marx.

Jerusalem 1969.

Meyer and Sáenz Badillos = Meyer, H. M. Z., and A. Sáenz Badillos. 'Incunabula'. In Encyclopaedia Judaica, 2nd ed. Edited by M. Berenbaum and F. Skolnik. Detroit 2007, vol. 9, pp. 757-69.

Oates = Oates, J.C.T. A Catalogue of the Fifteenth-Century Printed Books in the University Library Cambridge. Cambridge 1954.

Offenberg, Rosent. = Offenberg, A. K. 'Catalogue of the Hebrew Incunabula in the Bibliotheca Rosenthaliana. (I-III)'. Studia Rosenthaliana, 5 (1971), pp. 125-43, 246-67; 7 (1973), pp. 128-50.

Offenberg, Census = Offenberg, A. K. Hebrew Incunabula in Public Collections: A First International Census. In collaboration with C. Moed-Van Walraven. Nieuwkoop 1990.

Offenberg, BCM = Offenberg, A. K. Catalogue of Books Printed in the Fifteenth Century Now in the British (Museum) Library. Part XIII, Hebraica. London 2004.

Ohly and Sack = Ohly, K., and V. Sack. Inkunabelkatalog der Stadt- und Universitätsbibliothek und anderer öffentlicher Sammlungen in Frankfurt am Main. 5 vols. Frankfurt am Main, 1966-7.

Polain = Polain, L. Catalogue général des incunables des bibliothèques publiques de France. 23 vols. $(\mathrm{G}-\mathrm{Z})$. Nendeln 1970.

Polain $B=$ Polain, M. -L. Catalogue des livres imprimés au quinzième siècle des bibliothèques de Belgique. 5 vols. Brussels 1932-78. 
Pr. = Proctor, R. An Index to the Early Printed Books in the British Museum from the Invention of Printing to the Year 1500 with Notes of those in the Bodleian Library. London 1898. Reprint. London 1960; Mansfield 1999.

Roest $=$ Roest, M. Catalog der Hebraica ... aus der L. Rosenthal'schen Bibliothek. 2 vols. Amsterdam 1875.

$\mathrm{Schwab}=$ Schwab, M. Les incunables orientaux et les impressions orientales au commencement du XVIe siècle. Paris 1883. Reprint. Niewkoop 1964.

STCItaly $=$ Johnson, A. F. Short-Title Catalogue of Books Printed in Italy and of Italian Books Printed in Other Countries from 1465 to 1600 Now in the British Museum. London 1958.

STCSp-Port $=$ Thomas, H. Short-Title Catalogues of Spanish, Spanish-American and Portuguese Books Printed before 1601 in the British Museum. London 1966.

St.CB = Steinschneider, M. Catalogus librorum hebraeorum in bibliotheca Bodleiana . Berlin 1852-60. Reprint. Berlin 1931; Hildesheim 1964; Hildesheim-ZurichNew York 1998.

Striedl $=$ Striedl, H. 'Geschichte der Hebraica-Sammlung der Bayerschen Staatsbibliothek'. In Orientalisches aus Münchener Bibliotheken und Sammlungen. Edited by H. Franke, pp. 1-37 + 19 pp. of ill. Wiesbaden [1957]. TamaniParma = Tamani, G. 'Inventario degli incunaboli ebraici della Biblioteca Palatina di Parma'. La Bibliofilia, 75 (1973), pp. 239-81.

TamaniPiacenza $=$ Tamani, G. 'Inventario degli incunaboli ebraici della Biblioteca Comunale di Piacenza'. La Bibliofilia, 72 (1970), pp. 221-46.

TamaniSoncino = Tamani, G. Tipografia ebraica a Soncino 1483-1490. Catalogo della mostra. Soncino 1988. 
Thes = Thesaurus typographiae hebraicae saeculi XV. Edited by A. Freimann and M. Marx. 8 parts. Berlin 1924-1931. Reprint. Jerusalem c. 1967.

Thomas = Thomas, H. Short-Title Catalogues of Spanish, Spanish-American and Portuguese Books Printed before 1601 in the British Museum. London 1966. TishbyIsr $=$ Tishby, P. 'The Hebrew Incunabula in Israel' [Hebrew]. Kiryat Sefer, 59 (1983-4), pp. 946-58.

TishbyVat $=$ Tishby, P. 'The Hebrew Incunabula in the Biblioteca Apostolica of the Vatican’ [Hebrew]. Kiryat Sefer, 58 (1983=[1985]), pp. 853-7.

Van Straalen = Van Straalen, S. Catalogue of Hebrew Books in the British Museum Acquired during the Years 1868-92. London 1894.

VB = Voulliéme, E. Die Inkunabeln der Königlichen Bibliothek (Preussischen Staatsbibliothek) und der anderen Berliner Sammlungen. Leipzig 1906. (XXX. Beiheft zum ZfB; supplements: 1914, 1922, 1927).

Vindel $=$ Vindel, F. El arte tipográfico en España durante el siglo XV, 1-8. Madrid $1945-51$.

Vinograd = Vinograd, I. 'Oșar ha-sefer ha-'ivri: Reshimat ha-sefarim she-nidpesu be'ot 'ivrit me-re'shit ha-defus ha-'ivri bi-shenat 1469 'ad shenat 1863. Jerusalem 1994.

Wach. = Wachstein, B. Katalog der Salo Cohn'schen Schenkungen. II: Bücher aus der Sammlung S.H. Halberstam. Wien 1914.

Walsh, Harvard = Walsh, J. E. A Catalogue of the Fifteenth-Century Printed Books in the Harvard University Library. 5 vols. Binghamton NY, Tempe AZ, 1991-5. (Supplement ..., by David R. Whitesell. Harvard Library Bulletin, 16, nos. 1-2 [2005]).

Weiser = Weiser, R. (ed.) Books from Sefarad. Jerusalem 1992. 
Wiener = Wiener, S. Catalogus librorum impressorum hebraeorum in Museo Asiatico Scientiarum Rossicae asservatorum [Hebrew]. Petropoli, 1893-1918; 1936.

Yaari, Marks $=$ Yaari, A. Marks of Hebrew Printers from the Beginning of Printing until the End of the Nineteenth Century [Hebrew]. Jerusalem 1943.

Yerusalimsky = Yerusalimsky, A. 'Die Inkunabeln un der ideologišer kamf' [Yiddish]. Sovetiš Heymland (Nov. 1981), pp. 145-52.

Zaccaria $=$ Zaccaria, A. G. Serie di opera ebraiche impresse dai celebre tipografi Soncini. Fermo 1870. Reimp. Bologna 1970.

Zafren, Bible $=$ Zafren, H. C. 'Bible Editions, Bible Study and the Early History of Hebrew Printing'. Eretz-Israel: Archaeological, Historical and Geographical Studies, 16 (1982), pp. 240-51.

Zedner $=$ Catalogue of the Hebrew Books in the Library of the British Museum.

Compiled by J. Zedner. London 1867. Reprint. 1964.

Zehnacker $=$ Zehnacker, F. Catalogues régionaux des incunables des Bibliothèques publiques de France. Part 13. Région Alsace (Bas Rhin). 2 vols. Paris 1997. 